\title{
Kloning dan Analisis Bioinformatika Gen MSP1 Plasmodium falciparum Isolat Kota Jayapura
}

\author{
ARSYAM MAWARDI ${ }^{1 *}$, LEONARDO E. AISOI ${ }^{2}$, PAULA N. LEFAAN $^{3}$ \\ ${ }^{1}$ Jurusan Biologi, FMIPA Universitas Cenderawasih, Jayapura, Papua \\ ${ }^{2} J u r u s a n$ Pendidikan Biologi, FKIP Universitas Cenderawasih, Jayapura, Papua \\ ${ }^{3} J u r u s a n$ Ilmu Kesehatan Masyarakat, FKM Universitas Cenderawasih, Jayapura, Papua
}

Diterima: 21 September 2017 - Disetujui: 8 Maret 2018

(c) 2018 Jurusan Biologi FMIPA Universitas Cenderawasih

\begin{abstract}
Cloning gene involves the construction of a recombinant plasmid that inserted in a competent cell. On the other hand, genetic engineering requires bioinformatic analysis to be converted into tabulation and data interpretation. The study, titled "cloning block 2 MSP1 gene of Plasmodium falciparum isolate Jayapura city and bioinformatics analysis" is aimed to improve the technique of cloning the MSP1 gene of P. falciparum, initiated the creation of DH5a competent cells, ligations and transformations, plasmid isolation, confirmation the recombinant plasmid and able to perform bioinformatics analysis and construct phylogenetic tree. This study began with the manufacture of E. coli DH5a competent cells, MSP1 gene ligation in pJET1.2/blunt vector and transformation by using the heat shock transformation method, plasmid isolation of alkali lysis method, then plasmid confirmed by PCR and sequencing method, further sequence analysis and phylogenetic tree construction. The results showed that confirmation of MSP1 gene presence in pJET1.2/blunt with PCR was successful. From a total of 4 positive colonies grown in liquid culture, then isolated plasmid and confirmed with PCR obtained electroferogram bands with a size about $1049 \mathrm{bp}$ indicates the presence of MSP1 gene in plasmid. Based on the results, cloning of MSP1 gene using pJET1.2/blunt cloning vector and competent cell E. coli DH5a has been successfully performed. Bioinformatics analysis of sequencing result and phylogenetic tree were constructed successfully with 2 clusters isolate of malaria patients from Jayapura city.
\end{abstract}

Key words: Bioinformatics, cloning gene, heat shock transformation, MSP1, P. falciparum.

\section{PENDAHULUAN}

Penyakit malaria merupakan penyakit yang telah menginfeksi manusia hampir merata di seluruh dunia terutama di negara-negara beriklim tropis seperti Asia, Afrika dan Amerika tengah maupun selatan. Menurut World Health Organization (WHO) pada tahun 2016 terdapat sebanyak 196-263 juta kasus malaria dan 445 ribu kasus

\footnotetext{
* Alamat korespondensi:

PS. Biologi, Jurusan Biologi, FMIPA Uncen. Jl. Kamp.

Wolker, Waena, Jayapura, Papua. Telp./fax.:

+62967572115. e-mail: mawardiarsyam@gmail.com atau mawardiarsvam@unicen.ac.id
}

kematian akibat malaria (WHO, 2017). Hingga kini, telah banyak data penelitian tentang diversitas Plasmodium falciparum di Indonesia yang dijadikan sebagai acuan dan pembeda antara kasus pada $P$. falciparum dari suatu gen dengan kombinasi alel yang lainnya, dimana keberadaan alel berperan dalam patogenitasnya (Irawati, 2011; Strom et al., 2013).

Sejalan dengan apa yang dikemukakan oleh Sorontou \& Pakpahan (2015) bahwa gen-gen penyandi protein itulah yang menjadi penyebab malaria hampir merata di seluruh dunia terutama di negara-negara beriklim tropis. Lebih jauh, sulitnya penanganan malaria disebabkan karena secara genetik Plasmodium dapat bermutasi 
menjadi bentuk strain baru yang lebih resisten terhadap obat malaria. Disamping itu, terbentuknya variasi genetik yang berbeda, menyebabkan kemampuan dalam merespon terjadinya perubahan lingkungan menjadi lebih kuat (Sibley et al., 2011).

Kloning gen dewasa ini menjadi sebuah langkah untuk mendapatkan gen yang mungkin sangat dibutuhkan bagi kehidupan manusia. Kloning merupakan teknik penggandaan gen yang menghasilkan turunan yang sama sifat baik dari segi hereditas maupun penampakan dengan induknya ketika gen itu diekpresikan menjadi sebuah protein fungsional. Kloning gen pada intinya mencakup 2 hal yaitu proses ligasi dan transformasi (Koetschan et al., 2014).

Gen-gen $P$. falciparum yang beragam dan diekspresikan sebagai protein-protein permukaan merozoit (MSP) terkhusus MSP-1 adalah suatu bentuk variasi genetik yang terjadi dalam suatu populasi. Ini disebabkan beberapa hal, di antaranya peristiwa mutasi dan rekombinasi (Nurwidayati, 2010). Sementara itu, polimorfisme yang terdapat pada sejumlah gen seperti MSP1 yang mensintesa protein antigen dapat dipakai sebagai marker genetik untuk menentukan perbedaan genetik dari P. falciparum (Deborah et al., 2010). Kemajuan pesat dibidang rekayasa genetika dan bioteknologi molekular telah memudahkan identifikasi molekular melalui proses kloning.

Riset ini sangat bermanfaat untuk mengetahui efektivitas pJET1.2/blunt sebagai vektor kloning dan sel kompeten E. coli $\mathrm{DH} 5 \alpha$ sebagai bakteri transforman untuk menstorage gen penyandi Merozoite Surface Protein 1. Proses kloning gen MSP1 dapat dilakukan secara tepat, sehingga menyediakan stok gen pengkode MSP-1 yang hasilnya dapat menjadi langkah dasar untuk mendesain dan menganalisis antigen spesifik, maupun menentukan terapi yang mampu mencegah prevalensi penyakit malaria tropika, yang dinilai amat penting dalam upaya penanganan serta pencegahan malaria. Disamping itu, keberhasilan proses kloning dicapai dengan konfirmasi Polymerase Chain Reaction (PCR) dan sekuensing melalui pendekatan bioinformatika yang semakin memvalidasi hasil yang diperoleh.

Penelitian ini bertujuan untuk mengkloning gen MSP-1 Plasmodium menggunakan vektor pJET1.2/Blunt dan sel kompeten E. coli DH5, menganalisis efektivitas pJET1.2/Blunt sebagai vektor kloning dan sel kompeten E. coli DH5 $\alpha$ sebagai bakteri transforman, serta menggunakan pendekatan PCR, sekuensing dan analisis bioinformatika untuk konfirmasi keberhasilan kloning.

\section{METODE PENELITIAN}

Pembuatan Sel kompeten E. coli DH5 a, proses kloning, serta konfirmasi plasmid dengan PCR dilakukan di laboratorium analisis kromosom dan molekular Institut Teknologi Bandung. Sementara analisis bioinformatika dari hasil konfirmasi metode sekuensing dilakukan di laboratorium bioinformatika ITB. Penelitian dilakukan pada tanggal 15 Juli hingga 10 November 2017.

\section{Tahap persiapan Sampel}

Sampel diambil dari hasil purifikasi atau pemurnian amplikon gen MSP1. Gen MSP1 hasil purifikasi yang dipakai untuk setiap sampel sebanyak 50 mikroliter.

\section{Metode Kerja}

\section{Pembuatan Sel Kompeten Escherichia coli DH5 $\alpha$ dengan Metode Buffer CCMB}

Stok gliserol E. coli DH5a diinokulasi pada 5 $\mathrm{mL}$ medium LB cair dalam tabung falcon $15 \mathrm{~mL}$ steril dan diinkubasi pada shaker inkubator suhu $37{ }^{\circ} \mathrm{C}$ selama 12 jam. Lalu sebanyak $1 \mathrm{~mL}$ diinokulasi ke $50 \mathrm{~mL}$ medium LB dan diinkubasi pada shaker inkubator $37^{\circ} \mathrm{C}$ hingga ODnya mencapai 0,3-0,4. Sebanyak $12,5 \mathrm{~mL}$ E. coli $\mathrm{DH} 5 \mathrm{a}$ dengan OD 0,3-0,4 dialiquot ke tabung falcon 15 $\mathrm{mL}$ steril. Lalu tabung disentrifugasi pada kecepatan $14.000 \mathrm{rpm}$ dengan suhu $4{ }^{\circ} \mathrm{C}$ selama 10 menit, supernatan dibuang. Pelet ditambah dengan $4 \mathrm{~mL}$ buffer CCMB80 dingin (diresuspensi dengan $2 \mathrm{~mL}$ terlebih dahulu, lalu ditambahkan 
sisanya. Tips pipet ditempelkan ke tabung falcon. Larutan diinkubasi di dalam es selama 20 menit. Lalu disentrifugasi pada kecepatan $14.000 \mathrm{rpm}$ dengan suhu $4{ }^{\circ} \mathrm{C}$ selama 10 menit, supernatan dibuang. Pelet diresuspensi dengan $0,6 \mathrm{~mL}$ buffer CCMB80 dingin. Selanjutnya larutan diinkubasi di dalam es selama 20 menit. Larutan dialiquot ke dalam microtube 1,5 mL @100 $\mu \mathrm{L}$ (microtube didinginkan terlebih dahulu). Sel kompeten disimpan pada freezer suhu $-80^{\circ} \mathrm{C}$.

\section{Kloning Gen MSP1 dalam Vektor Kloning pJET1.2/Blunt}

Ligasi Gen MSP1. Gen MSP1 diligasi dengan tahapan: pembuatan blunting reaction diatas es yang terdiri dari $10 \mu \mathrm{L} 2$ X reaction buffer, $1 \mu \mathrm{L} 0,15$ pmol ends DNA template, Air bebas nuklease hingga $17 \mu \mathrm{L}$, enzim DNA blunting $1 \mu \mathrm{L}$. Larutan divortex sampai homogen dan disentrifugasi selama 3-5 detik. Selanjutnya larutan diinkubasi pada suhu $70^{\circ} \mathrm{C}$ selama 5 menit, lalu didinginkan menggunakan es. Pembuatan ligation reaction di atas es yang terdiri dari $1 \mu \mathrm{L}(0,05$ pmol $)$ pJET1.2/blunt cloning vector $(50 \mathrm{ng} / \mu \mathrm{L}), 1 \mu \mathrm{L} \mathrm{T} 4$ DNA ligase. Larutan divortex dan disentrifugasi selama 3-5 detik. Campuran ligasi diinkubasi pada suhu ruang $\left(22{ }^{\circ} \mathrm{C}\right)$ selama 5 menit. Campuran ligasi harus segera digunakan.

Transformasi dengan Metode Heat Shock Transformation. Sel kompeten E. coli DH5a diambil dari tempat penyimpanan suhu $-80^{\circ} \mathrm{C}$. Sel kompeten dicairkan dan diinkubasi didalam es selama 10 menit. Selanjutnya plasmid pJET1.2/ blunt hasil kloning dimasukkan ke dalam tabung microtube sebanyak $10 \mu \mathrm{L}$ yang telah berisi $100 \mu \mathrm{L}$ sel kompeten. Tabung dijentik beberapa kali kemudian diinkubasi di dalam es selama 30 menit. Tabung diberi kejut panas dengan cara diinkubasi dalam water bath suhu $42{ }^{\circ} \mathrm{C}$ selama 90 detik, kemudian diinkubasi kembali di dalam es selama 10 menit. Sebanyak $600 \mu \mathrm{L}$ SOC ditambahkan kedalam tabung kemudian diinkubasi dan dikocok pada suhu $37^{\circ} \mathrm{C}$ selama 2-3 jam dengan kecepatan shaker $250 \mathrm{rpm}$. Sebanyak $100 \mu \mathrm{L}$ kultur E. coli DH5a hasil transformasi dituang dan disebarkan secara merata di atas permukaan medium LB padat yang mengandung $100 \mu \mathrm{g} / \mathrm{ml}$ antibiotik ampisilin pada cawan petri menggunakan batang L. Cawan petri diinkubasi pada suhu $37^{\circ} \mathrm{C}$ selama $16-18$ jam. Lalu diamati.

\section{Isolasi Plasmid pJET1.2/blunt dari E. coli DH5a.}

Pre treatment solution. RNAse A solution terlebih dahulu ditambahkan ke resuspension solution, lalu dimix hingga larut. Resuspension solution yang telah ditambahkan RNAse A disimpan di kulkas $4{ }^{\circ} \mathrm{C}$. Etanol $96 \%$ ditambahkan ke wash solution sebelum pertama kali digunakan. Presipitat-presipitat garam yang ada di lysis solution dan neutralization solution dilarutkan kembali dengan cara memanaskannya di suhu 37 ${ }^{\circ} \mathrm{C}$, lalu didinginkan kembali di suhu ruang (suhu $25^{\circ} \mathrm{C}$ ) sebelum digunakan. Botol yang berisi lysis solution dicampur dan dihomogenkan secara perlahan.

Prosedur isolasi plasmid. Langkah kerja diawali dengan pemanenan sel. 1,5 mL LB cair hasil kultur cair dimasukkan ke dalam microtube 1,5 mL, lalu disentrifugasi pada kecepatan 14000 rpm selama 1 menit, kemudian supernatan dibuang. Pelet yang ada ditambahkan lagi dengan 1,5 mL LB cair hasil kultur cair. Disentrifugasi kembali pada kecepatan 14000 rpm selama 1 menit dan supernatan dibuang. Langkah ini terus dilakukan sampai semua kultur cair habis. Pelet terakhir yang didapatkan kemudian ditambahkan $250 \mu \mathrm{L}$ resuspension solution yang sebelumnya telah ditambahkan RNAse A. Lalu, divorteks hingga semua pelet terlarut. Selanjutnya ditambahkan 250 $\mu \mathrm{L}$ lysis solution dan dibolak-balik sebanyak 4-6 kali secara perlahan, sampai solution menjadi kental dan terlihat jernih (microtube yang telah ditambahkan lysis solution tidak divorteks agar DNA kromosomal tidak terpotong-potong atau rusak). Dilanjutkan dengan menambahkan $350 \mu \mathrm{L}$ neutralization solution dan dibolak-balik secara cepat selama 4-6 kali. Kemudian disentrifugasi $14000 \mathrm{rpm}$ selama 5 menit. Semua supernatan yang terbentuk setelah sentrifugasi, dipindahkan ke GeneJET spin column yang telah dipasang pada collection tube $2 \mathrm{~mL}$. Presipitat putih jangan sampai ikut terambil. Lalu, disentrifugasi $14000 \mathrm{rpm}$ selama 1 menit. Cairan tersisa yang terdapat pada 
collection tube dibuang dan GeneJET spin column ditempatkan kembali. Kemudian ditambahkan 500 $\mu \mathrm{L}$ wash solution yang sebelumnya telah ditambahkan etanol, lalu disentrifugasi $14000 \mathrm{rpm}$ selama 1 menit. Cairan yang tersisa pada collection tube dibuang. GeneJET spin column kembali ditempatkan pada collection tube. Lalu disentrifugasi selama 1 menit 14000 rpm untuk menghilangkan residu dari Wash Solution sebelumnya. GeneJET spin column yang telah kering selanjutnya ditempatkan pada microtube 1,5 $\mathrm{mL}$ baru. Kemudian ditambahkan elution buffer 25 $\mu \mathrm{L}$ dan dibiarkan selama 2 menit agar terserap semua pada matriks kolom. Kemudian disentrifugasi $14000 \mathrm{rpm}$ selama 2 menit. Lalu ditambahkan lagi $25 \mu \mathrm{L}$ elution buffer, dibiarkan selama 2 menit dan disentrifugasi selama 2 menit $14000 \mathrm{rpm}$. Selanjutnya hasil isolasi plasmid langsung dielektroforesis. Volume plasmid yang dimasukkan adalah $5 \mu \mathrm{L}$. Selanjutnya diresuspensi dengan $1 \mu \mathrm{L}$ loading dye di atas kertas parafilm. Setelah elektroforesis, hasil isolasi plasmid disimpan di kulkas $-20^{\circ} \mathrm{C}$.

Konfirmasi Plasmid Rekombinan pJET1.2/blunt dengan Metode PCR dan Sekuensing

Konfirmasi Plasmid Rekombinan

pJET1.2/blunt dengan Metode PCR. Master mix PCR dibuat untuk 5/6 sampel dalam microtube 1,5 $\mathrm{ml}$. Pembuatan dilakukan dalam kondisi dingin. Komposisi master mix: air deion $3 \mu \mathrm{L}$, dream taq PCR master mix $5 \mu \mathrm{L}$, primer forward $0,5 \mu \mathrm{L}$, primer reverse 0,5 $\mu \mathrm{L}$. Pembuatan reaksi PCR untuk MSP1dengan cara mentransfer master mix PCR dan sebanyak $1 \mu \mathrm{L}$ sampel plasmid pJET1.2/blunt (yang diinsersi dengan gen MSP1) ke dalam tube PCR. Pembuatan dilakukan dalam kondisi dingin. Tube PCR diquick spin. Tube PCR diletakkan dalam thermocycler machine dengan kondisi: pradenaturasi suhu $95{ }^{\circ} \mathrm{C}$ selama 3 menit, denaturasi suhu $95^{\circ} \mathrm{C}$ selama 30 detik, annealing selama 30 detik dengan suhu annealing $55^{\circ} \mathrm{C}$, ekstensi suhu $72{ }^{\circ} \mathrm{C}$ selama 2 menit, final ekstensi suhu $72{ }^{\circ} \mathrm{C}$ selama 7 menit. Lalu diamati dengan elektroforesis gel agarosa.

Konfirmasi Plasmid Rekombinan pJET1.2/ blunt dengan Metode Sekuensing. Data hasil sekuensing dianalisis lebih lanjut dengan cara dipotong sekuens DNAnya yang merupakan representasi kromatogram. Sekuens yang dipotong adalah sekuens yang pola grafiknya kurang baik dan tumpang tindih. Pemotongan dan pengeditan dilakukan dengan software Bioedit. Setelah itu, Data sekuens forward dan reverse dilakukan proses contig, yang sebelumnya sekuens reverse telah diatur menjadi reverse complement. Kemudian dilanjutkan dengan analisis vecscreen dan analisis blast.

\section{Konstruksi Pohon Filogenetik}

Analisis pohon filogenetik dilakukan dengan menggunakan software MEGA 6. Pada tahapan ini, sebanyak 5 sekuens dipilih yakni sampel, 10 sekuens yang berkerabat dekat, dan 1 sekuens untuk outgroup.

\section{Teknik Pengumpulan Data}

Data hasil perlakuan diperoleh dengan banyaknya dengan menggunakan teknis elektroforesis gel agarosa. Untuk mengetahui kuantitas dan kualitas DNA maka dilakukan pengecekan dengan menggunakan agarose $2 \%$, TAE 1x. Gel agarose dielektroforesis pada tegangan listrik 100 volt selama 25 menit.

Visualisasi dilakukan dengan pendaran cahaya pada UV transiluminator, yang dilengkapi dengan cahaya UV dan divisualisasi dengan kamera sinar ultraviolet pada panjang gelombang $300 \mathrm{~nm}$. DNA memunculkan pendaran akibat ethidium bromida. Dari hasil itu terlihat band atau profil pita yang menunjukkan ukuran basa nukleotida dari gen tersebut.

Hasil kloning gen MSP1 dikirimkan ke Macrogen Corporation Korea untuk mendapatkan data hasil sekuensing berupa data kromatogram atau kurva beserta urutan nukleotida.

\section{Analisis Bioinformatika dan Pengolahan Data}

Hasil elektroforesis dari amplifikasi, kloning gen MSP1 blok 2, dianalisis dengan melihat ukuran basa nukleotida, dan data sekuens dari macrogen. Ukuran basa nukleotida memperlihatkan ukuran spesifik dari gen MSP1. Begitupula dengan data sekuensing diolah dengan beberapa 
software untuk pendekatan bioinfomatika. Data disajikan secara naratif deskriptif.

\section{HASIL DAN PEMBAHASAN}

\section{Hasil Purifikasi Produk PCR}

Hasil amplifikasi berupa produk PCR, melalui proses purifikasi untuk menghilangkan segala kontaminan dan inhibitor yang masih tersisa. Proses purifikasi amatlah penting karena

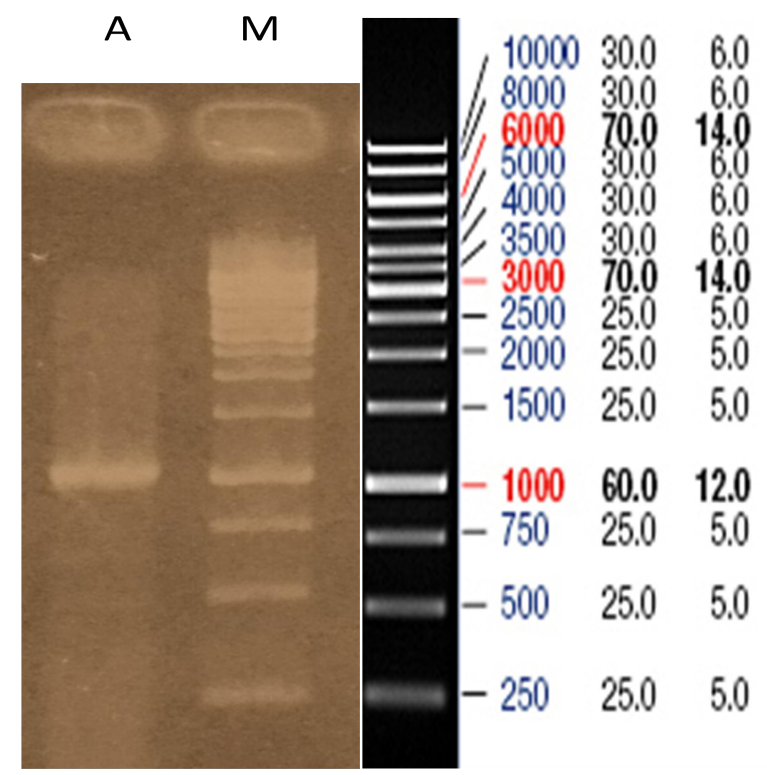

Gambar 1. Elektroferogram hasil purifikasi produk PCR. (M= DNA Ladder $1 \mathrm{~kb}, \mathrm{~A}=$ hasil purifikasi, 1049 bp).

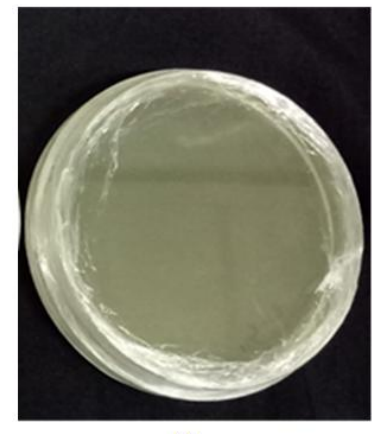

$(-)$

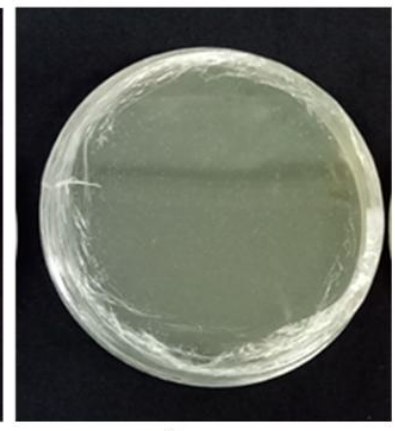

$+$
Gambar 2. Koloni sel kompeten E. coli DH5 $\alpha$ transforman. (-): Kontrol negatif tidak tumbuh koloni bakteri, (+): Media yang ditumbuhi bakteri transforman. keberhasilan kloning juga ditentukan oleh ketepatan dalam melakukan purifikasi hasil PCR. Secara umum, proses purifikasi melibatkan matriks kolom. Produk PCR akan tertarik dari matrix sehingga akan diperoleh larutan yang berisi amplikon yang murni. Untuk mengecek keberhasilan proses purifikasi, dilakukan elektroforesis (Gambar 1). Pola pita yang dihasilkan setelah purifikasi akan terlihat lebih terang dan jernih, serta tidak ada lagi pita smear. Sehingga yang terlihat hanya pita tunggal yang berukuran $1049 \mathrm{bp}$.

\section{Produk Sel Kompeten Escherichia coli DH5a}

Bakteri yang mampu mengambil DNA disebut sel kompeten dan kompetensi sel dapat diinduksi dengan penambahan dengan kalsium klorida pada fase log awal pertumbuhan (Tu et al., 2005). Sel kompeten E. coli DH5a diinkubasi selama 12 jam dalam medium LB cair, dengan acuan bahwa lama waktu tersebut diperkirakan $E$. coli telah mengalami fase log. Fase log diperlukan agar jumlah bakteri yang terisolasi berada pada kondisi optimal (Najia et al., 2010). Penambahan buffer $\mathrm{CCMB}$ yang mengandung $\mathrm{MgCl} 2$ berfungsi untuk menurunkan kerapatan membran sel melalui interaksi $\mathrm{Mg} 2+$ dengan bagian hidrofilik membran (Zhang et al., 2007). Selain itu juga mengandung $\mathrm{CaCl} 2$ yang dapat mempengaruhi bentuk dinding sel, membran bakteri permeable pada ion Cl-. Pada saat ion Cl- masuk ke dalam membran molekul air menyertai ion $\mathrm{Cl}$ - sehingga menyebabkan sel membengkak dan kondisi ini diperlukan untuk pengambilan DNA (Primrose \& Twyman, 2006; Tu et al., 2005). Adapun keseluruhan pengerjaan sel kompeten dilakukan pada suhu dingin bertujuan untuk mempertahankan fungsinya sebagai sel kompeten (Tu et al., 2005; Hwang et al., 2012).

\section{Hasil Ligasi MSP1 ke dalam Vektor Kloning pJET1.2/Blunt}

Kloning Gen MSP1 dilakukan dengan menggunakan vektor kloning pJET1.2/blunt. Plasmid ini mempunyai ukuran 2974 bp, blunt end, sistem seleksi menggunakan ampisilin dan sistem reporter gene menggunakan gen letal 
(eco471R) (Primrose \& Twyman, 2006). DNA hasil PCR mempunyai over hang karena DNA polymerase yang digunakan adalah Green Taq DNA polimerase. Enzim Green Taq DNA polymerase menghasilkan produk dengan ujung kohesif atau sticky end. Oleh karena itu, supaya DNA hasil PCR tersebut dapat diligasikan ke vektor kloning digunakan enzim blunting DNA yang berfungsi untuk memotong ujung DNA hasil PCR menjadi blunt end. Ujung DNA dibuat blunt end karena vektor kloning pJET1.2/blunt juga mempunyai ujung blunt end. Selanjutnya DNA hasil PCR diligasikan kedalam pJET1.2/blunt menggunakan enzim T4 DNA ligase. DNA ligase berfungsi untuk mengkatalis pembentukan ikatan fosfodiester

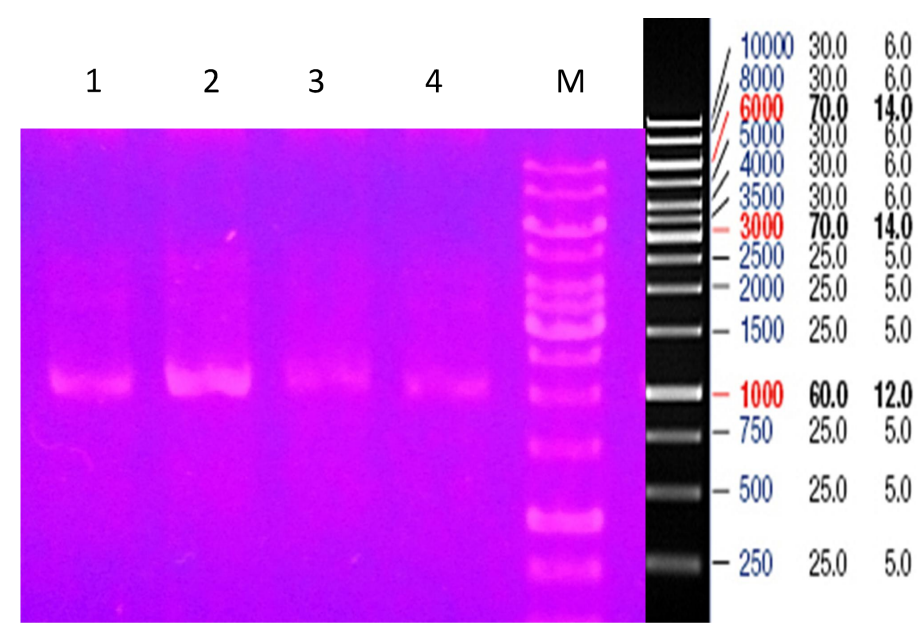

Gambar 3. Elektroferogram hasil isolasi plasmid. (M= DNA Ladder $1 \mathrm{~kb}, 1-4=$ plasmid).

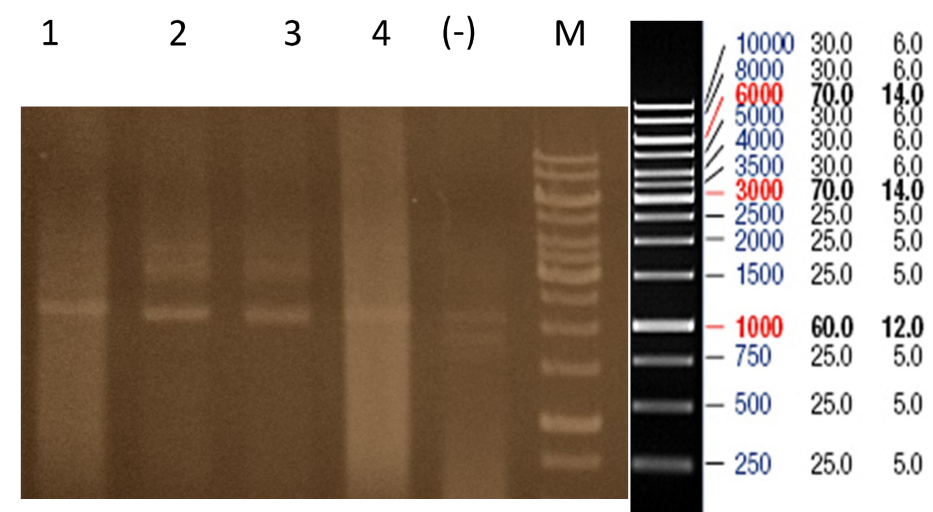

Gambar 4. Elektroferogram konfirmasi plasmid dengan PCR ( $\mathrm{L}=$ DNA Ladder $1 \mathrm{~kb}, 1-18=$ plasmid). anatara fragmen DNA target dengan fragmen plasmid (Thieman \& Michael, 2013).

Untuk mengetahui keberhasilan ligasi maka pengamatan dilakukan setelah melakukan transformasi E. coli DH5a dengan plasmid pJET1.2/blunt rekombinan dan dibiakkan dalam media seleksi, sehingga membentuk koloni. Koloni yang dapat tumbuh pada media seleksi ini merupakan salah satu parameter yang menunjukan bahwa DNA target masuk kedalam pJET1.2/blunt.

\section{Plasmid Transforman}

Transformasi merupakan metode penginsersian materi genetik kedalam sel bakteri melalui direct uptake dari lingkungan. Heat shock transformation adalah metode untuk memasukan plasmid rekombinan ke dalam sel kompeten E. coli DH5a dengan cara memberi kejut panas (Tu et al., 2005). Pemanasan dilakukan untuk membuat pori sel membuka. Suhu $42{ }^{\circ} \mathrm{C}$ digunakan karena $E$. coli masih bisa bertahan pada suhu tersebut, diatas suhu $42{ }^{\circ} \mathrm{C}$ kemampuan E. coli untuk mengambil DNA menurun bahkan bisa menyebabkan sel E. coli mati (Tu et al., 2005).

Untuk mengetahui keberhasilan transformasi maka dilakukan seleksi dengan menumbuhkan kultur E. coli hasil transformasi pada medium yang mengandung ampisilin. Dengan adanya ampisilin, maka sel E. coli yang dapat tumbuh hanya sel yang mengandung plasmid pJET1.2/blunt karena plasmid ini mempunyai ampisilin resisten.

Proses transformasi berhasil dilakukan (Gambar 2). Hal ini ditandai dengan adanya koloni yang tumbuh sebanyak 29 koloni pada medium LB padat yang mengandung ampisilin dan IPTG. Dengan demikian pembuatan sel kompeten sudah tepat sehingga sel dapat menerima atau mengambil DNA. Proses ligasi pun tepat jadi DNA target dapat diinsersi ke plasmid. Hal ini membuat gen letal (eco417R) tidak terekspresi dan menyebabkan sel hidup. Gen letal terletak pada sekuen Multi Cloning Site (MCS) yang terdapat di pJET1.2/blunt, gen letal akan diekspresikan jika tidak ada DNA 
target yang masuk di sekuen MCS. Faktor lain yang menjadi kunci keberhasilan transformasi adalah proses heat shock transformation yang sudah tepat sehingga plasmid yang sudah diinsersi dengan DNA target masuk kedalam sel kompeten. Hal ini menyebabkan sel mampu tumbuh pada medium LB padat yang diberi ampisilin dan IPTG karena sel mengandung plasmid rekombinan yang resisten terhadap ampisilin serta induksi IPTG yang apabila daerah MCS diisi oleh gen insert, maka gen letal tidak terekpresikan dan menyebabkan tumbuhnya koloni berwarna putih.

\section{Isolat Plasmid pJET1.2/blunt dari E. coli DH5 $\alpha$}

Isolasi Plasmid bertujuan untuk mengisolasi plasmid rekombinan dari sel kompeten. Isolasi plasmid menggunakan beberapa larutan yaitu larutan resuspensi yang berfungsi untuk melarutkan sel, larutan ini berisi Tris yang berfungsi sebagai larutan penyangga, EDTA yang berfungsi untuk mengikat kofaktor agar DNA tidak didegradasi oleh DNAse, glukosa untuk menjaga tekanan osmosis sel larutan. larutan lisis berfungsi untuk melepaskan plasmid dari sel $E$. coli DH5a, larutan ini berisi SDS yang berfungsi untuk mengikat membran sel, $\mathrm{NaOH}$ berfungsi untuk memecahkan dinding sel dan mendenaturasi DNA untuk memisahkan DNA plasmid dan DNA kromosom. Larutan netralisasi berfungsi untuk menetralkan larutan agar DNA plasmid dapat direnaturasi sehingga DNA plasmid dapat terikat pada membran silika di spin column (Birkenmeyer et al., 2010). Larutan pencuci yang mengandung etanol berfungsi untuk mengendapkan DNA plasmid pada membran silika dan menghilangkan garam-garam dan pengotor lainnya. Larutan elusi berfungsi untuk melarutkan DNA plasmid yang terikat pada membran silika (Poh \& Gan, 2014; Faatih, 2009).

Berdasarkan hasil elektroforesis pada gambar tiga, isolasi plasmid pJET1.2/blunt yang diinsersi dengan gen MSP1 berhasil dilakukan. Hal ini ditandai dengan adanya pita yang terbentuk. Ukurannya adalah berkisar 1500- 2000 bp, 3000 bp dan 3500 bp. Sehingga diasumsikan DNA plasmid yang ukurannya sekitar 1-3 kb dapat dengan mudah dibedakan dengan DNA kromosom bakteri yang berkisar 3-5 kb.

Dari hasil elektroforesis dapat dilihat bahwa pita yang muncul lebih dari satu. Pita-pita tersebut merupakan plasmid dengan konformasi yang berbeda-beda. Konformasi plasmid dapat berupa covalently closed circular, open circular dan supercoil, masing-masing mempunyai kecepatan migrasi yang berbeda (Primrose \& Twyman, 2006; Kang et al., 2010 ). Terlihat ada pita yang trelihat smear, hal ini terjadi saat DNA dicuci dengan etanol absolut, pelet terlepas saat pembuangan etanol absolut dan pelet pun ikut terbuang (Mawardi \& Simonapendi, 2016). Selain itu, untuk mengetahui keberadaan gen insert didalam plasmid yang sudah diisolasi dapat dikonfirmasi dengan teknik PCR dan sekuensing.

\section{Hasil Konfirmasi Plasmid Rekombinan pJET1.2/blunt dengan Metode PCR dan Sekuensing}

Konfirmasi keberadaan gen MSP1 dalam pJET1.2/blunt hasil transformasi dengan PCR berhasil dilakukan (Gambar 4). Hal ini ditandai dengan adanya pita pada hasil elektroforesis dengan ukuran 1600 bp yang menunjukan gen MSP1. Hal ini juga menunjukan bahwa gen MSP1 berhasil diinsersi kedalam pJET1.2/blunt.

Konfirmasi yang kedua adalah melalui metode sekuensing. Diperoleh kromatogram hasil pembacaan secara forward dan reverse. Proses sekuensing dilakukan oleh Macrogen Corporation. Dari hasil sekuensing tersebut akan didapatkan kromatogram yang menunjukkan spektrum dan intensitas tertentu. Semakin tinggi konsentrasi plasmid maka spektrum hasil sekuensing akan semakin baik.

Ukuran dari DNA target yang berukuran \pm 1049 bp, sehingga sekuensing dilakukan 2 arah, agar dapat diketahui seluruh urutan nukleotida DNA target. Hasil sekuensing dari tiap reaksi, dilakukan proses contig dengan melakukan reverse complement terlebih dahulu pada urutan reverse yang nantinya akan menghasilkan urutan DNA tanpa celah yang dinamakan daerah lestari atau consensus. Pengolahan data hasil sekuensing menggunakan software BioEdit. 


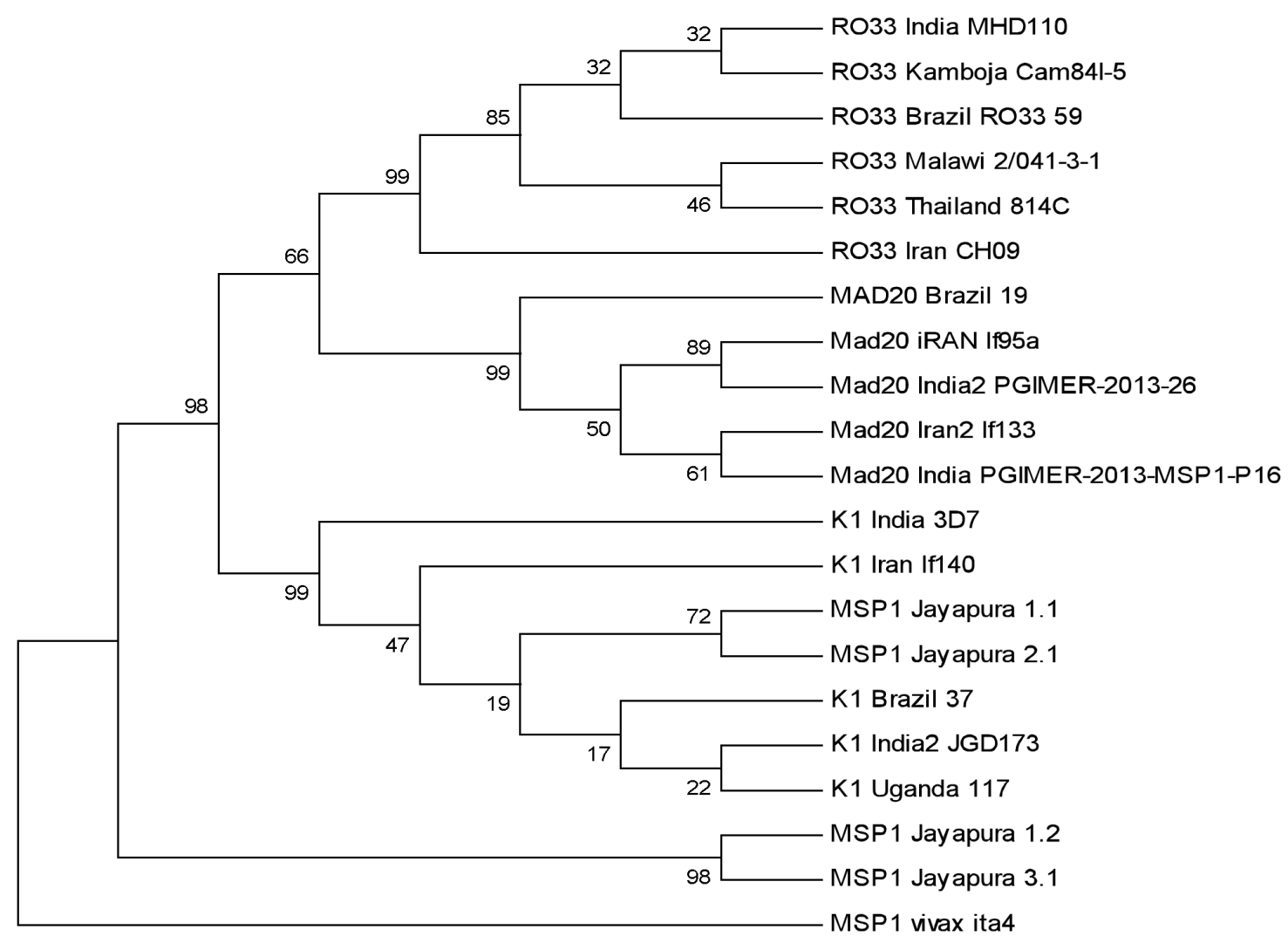

Gambar 5. Konstruksi pohon filogenetik menggunakan metode algoritma Neighbor Joining, dengan nilai bootstrap 1000.

\section{Hasil Konstruksi Pohon Filogenetik}

Konstruksi pohon filogenetik dimaksudkan mengetahui filogeni dan menunjukkan hubungan evolusi antar organisme (hubungan kekerabatan), dimana sampel memiliki sifat yang mirip dengan kerabat terdekat karena sejenis. Untuk melakukan analisis kontruksi pohon filogenetik pada penelitian ini ditentukan outgroup yang berada pada level yang berbeda dengan seluruh sekuens yang dibandingkan.

Kontruksi pohon filogenetik diawali dengan proses alignment terhadap 12 sekuens menggunakan program ClustalX. Program ini akan melakukan pensejajaran terhadap 12 sekuens. Hasil dari pensejajaran oleh ClustalX kemudian dianalisis untuk mendapatkan konstruksi pohon filogenetik menggunakan program MEGA 6. Hubungan kekerabatan dari sekuens MSP1 $P$. falciparum dan beberapa sekuens yang berkerabat dekat serta 1 sekuens outgroup dapat dilihat dari pohon filogenetik yang terbentuk.

Berdasarkan input data pada program MEGA 6, didapatkan kontruksi pohon filogenetik yang menggambarkan kemiripan antara sesama sampel gen MSP1 Jayapura dengan basis data pada bank gen. Pada gambar 5, Terbentuk 2 klaster besar yaitu MSP1 Jayapura 1.1, MSP1 Jayapura 2.1, dan K1 dari berbagai negara berada dalam satu klaster, sementara MSP1 Jayapura 1.2, dan MSP1 Jayapura 3.1, mengelompok pada klaster yang lain. Terlihat pada gambar 5 bahwa MSP1 Jayapura 1.2, dan MSP1 Jayapura 3.1 terpisah dan memiliki klaster tersendiri di antara isolat yang lain. Hal ini sangat menarik bahwa terdapat kemungkinan dua isolat tersebut memang benar-benar berbeda, memiliki diversitas atau kombinasi alel yang menyebabkan adanya variasi MSP1 pada kedua isolat. Konstruksi pohon 
filogenetik juga dimaksudkan untuk mengetahui filogeni dan memperlihatkan hubungan kekerabatan, dimana sampel yang memiliki kemiripan sifat akan berada pada posisi yang berdekatan dalam pohon filogenetik karena memiliki sekuens DNA yang identik atau mempunyai banyak kesamaan. Untuk melakukan analisis kontruksi pohon filogenetik pada penelitian ini, ditentukan outgroup yang berada pada level yang berbeda dengan seluruh sekuens yang dibandingkan, yaitu MSP1 vivax ita4, berada pada klaster yang juga berbeda dari 2 klaster sebelumnya, karena MSP1 vivax ita4 telah diposisikan sebagai sampel outgrup yang memang berbeda pada tingkat spesies.

Pohon filogenetik tersebut dikonstruksi dengan metode algoritma Neighbor Joining, dan nilai bootstrap 1000. Adapun angka yang tertera pada pohon filogenetik menunjukkan kredibilitas, konsistensi dan tingkat kekokohan dari pohon tersebut.

\section{KESIMPULAN}

Berdasarkan hasil pengamatan dapat disimpulan bahwa kloning gen merupakan serangkaian proses menggandakan material genetic agar memiliki sifat yang sama secara hereditas dan fenotip. Kloning gen meliputi: pembuatan sel kompeten, ligasi dan transformasi, pemurnian, dan pengenceran.

Pembuatan sel kompeten dengan metode buffer CCMB berhasil dilakukan. Begitu pula ligasi dan transformasi pJET 1,2/blunt ke dalam $E$. coli DH5 $\alpha$ dengan metode heat shock berhasil dilakukan, dibuktikan dengan tumbuhnya koloni putih pada medium yang telah ditambahkan ampisilin dan IPTG.

Metode alkali lisis efektif dan berhasil dilakukan dalam proses isolasi plasmid pJET 1,2/blunt dari bakteri Escherichia coli DH5 $\alpha$. Konfirmasi plasmid dengan PCR dan sekuensing untuk deteksi MSP1 berhasil dilakukan, terbukti dari pita elektroferogram berukuran 1049 bp, dan sekuens gen MSP1 yang sesuai dengan data bank gen NCBI. Analisis bioinformatika hasil sekuensing dan konstruksi pohon filogenetik berhasil dilakukan dengan terbentuknya 2 klaster pada isolat pasien malaria yang berasal dari kota Jayapura.

\section{DAFTAR PUSTAKA}

Birkenmeyer, L., M.A. Scott, J.D. George, and M.D. Suresh. 2010. Isolation and characterization of the MSP1 genes from Plasmodium malariae and Plasmodium ovale. The American Journal of Tropical Medicine and Hygiene. 82(6): 996-1003.

Deborah, S., Ken M.H, P.M. Joseph, and A. Salim. 2010. Genetic diversity of Plasmodium falciparum strains in children under five years of age in Southeastern Tanzania. The Open Tropical Medicine Journal. 3: 10-14.

Faatih, M. 2009. Isolasi dan digesti DNA kromosom.Jurnal Penelitian Sains dan Teknologi. 10(1): 61-67.

Hwang, J., J. Jaroensuk, M. Leimanis, B. Russell, R. McGready, N. Day, G. Snounou, F. Nosten, and M. Imwong. 2012. Long-term storage limits PCR-based analyses of malaria parasites in archival dried blood spots. Malaria Journal. 11(1): $1-7$

Irawati, N. 2011. Genetic polymorphism of merozoite surface protein-1 (msp-1) block 2 allelic types in Plasmodium falciparum field isolates from mountain and coastal area in West Sumatera, Indonesia. Medical Journal Indonesia. 20: 11-14.

Kang J.M, S.U. Moon, J.Y. Kim, S.H. Cho, K. Lin, W.M. Sohn, T.S. Kim, and B.K. Na. 2010. Genetic Polymorhism of merozoite surface protein-1 and merozoite surface protein-2 in Plasmodium falciparum field isolates from Myanmar. Malaria Journal. 9: 131-138.

Koetschan C., S. Kittelmann, J. Lu, D. Al-Halbouni, G.N. Jarvis, T. Muller, M. Wolf, and P.H. Janssen. 2014. Internal transcribed spacer 1 secondary structure analysis reveals a common core throughout the anaerobic fungi (Neocallimastigomycota). PLoS ONE. 9(3): e91928.

Mawardi, A., dan M.L. Simonapendi. 2016. Uji efektivitas metode isolasi DNA genom kopi arabika (Coffea arabica L.) asal kabupaten Jayawijaya. Jurnal Biologi Papua. 8(1): 7-12

Nurwidayati, A. 2010. Review artikel: Respon antibodi terhadap protein permukaan merozoite Plasmodium falciparum dalam penentuan transmisi malaria. Jurnal Vektor Penyakit. 4(1): 17-25.

Najia, K.G., M. Andreas, U. Johan, J. San, B. Sándor, H. Rabia, and A.B. Mohammad. 2010. Genetic diversity among Plasmodium falciparum field isolates in Pakistan measured with PCR genotyping of the merozoite surface protein 1 and 2. Malaria Journal. 9: 1-3.

Poh, J.J., and S.K.E. Gan. 2014. The Determination of factors involved in column based nucleic acid extraction and 
purification. Journal Bioprocessing and Biotechniques. 4(3): 157-161.

Primrose, S.B., and R.M. Twyman. 2006. Principles of gene manipulation and genomics. $7^{\text {th }}$ Edition. Blackwell Publishing. Australia.

Sibley, C.H., , J.E. Hyde, P.F.G. Sims, C.V. Plowe, J.G. Kublin, E.K. Mberu, A.F. Cowman, P.A. Winstanley, W.M. Watkins, and A.M. Nzila. 2001. Pyrimethaminesulfadoxine resistance in Plasmodium falciparum: what next?. Trends Parasitol. 17(12): 582-588.

Sorontou, Y., and A. Pakpahan. 2015. Genetic diversity in MSP-1 gene of Plasmodium falciparum and its association with malaria severity, parasite density, and host factors of asymptomatic and smptomatic patients in Papua, Indonesia. International Journal of Medical Science and Public Health. 4(11): 1584-1593.

Strom, G.E., C.G. Haanshuus, M. Fataki, N. Langeland,, and B. Blomberg. 2013. Challenges in diagnosing paediatric malaria in Dar es Salaam, Tanzania. Malaria Journal. 12: 228-237.

Tu, Z., G.He, K.X. Li, M.J. Chen, J. Chang, L. Chen, Q. Yao, Liu, D.P., H. Ye, J. Shi, and X. Wu. 2005. An improved system for competent cell preparation and high efficiency plasmid transformation using different Escherichia coli strains. Electronic Journal of Biotechnology. 8(1): 114-120.

Thieman, W.J., and A.P. Michael. 2013. Introduction to biotechnology. USA : Pearson.

WHO. 2017. World Malaria Report. World Health Organization. Geneva.

Zhang. H., Z. Zhang, J. Li, S. Cai. 2007. Effects of Mg2+ on supported bilayer membrane on a glassy carbon electrode during membrane formation. International Journal of Electrochemical Science. 2: 788-796. 